\title{
Ball possession effectiveness in men's and women's elite basketball according to situational variables in different game periods
}

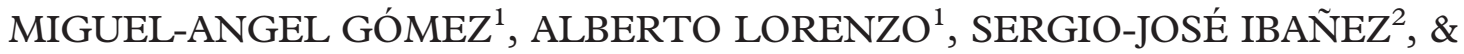 \\ JAIME SAMPAIO 3 \\ ${ }^{1}$ Faculty of Physical Activity and Sport Sciences, Polytechnic University of Madrid, Madrid, Spain, ${ }^{2}$ University of \\ Extremadura, Faculty of Sport Sciences, Av. Universidad s/n, Caceres, 10171 Spain, and ${ }^{3}$ Universidade de Trás-Os-Montes e \\ Alto Douro, Sport Sciences Department, Quinta de Prados, ap 202, Vila Real, 5000 Portugal
}

(Accepted 22 March 2013)

\begin{abstract}
The aim of the present study was to identify the importance of basketball performance indicators in predicting the effectiveness of ball possessions in men's and women's basketball, when controlling for situational variables and game periods. The sample consisted of 7234 ball possessions, corresponding to 40 games from the Spanish professional leagues. The effects of the predictor variables on successful ball possessions according to game period were analysed using binary logistic regressions. Results from men's teams show interactions with number of passes and ending player during the first five minutes, with starting and ending zone, defensive systems, screens used and possession duration during the middle thirty minutes, and there were interactions with passes used, possession duration and players involved during the last five minutes. Results from women's teams show interactions with starting and ending zone, passes used, defensive systems and ending player during the first five minutes, and with starting and ending zone, and screens used during the middle thirty minutes. The results show no interaction with situational variables in men's basketball, while league stage was important during the middle thirty minutes and last five minutes in women's basketball, whereas match status was only important during the last five minutes.
\end{abstract}

Keywords: situational variables, team sports, performance analysis, binary regression, performance indicators

\section{Introduction}

One of the most important tasks for basketball coaches is to prepare practice sessions according to competition constraints (Hughes \& Bartlett, 2002; Sampaio, Lago, \& Drinkwater, 2010). The available research has helped to identify and describe the performance indicators that allow discrimination of teams' performances according to game final outcome in different situations (Gómez, Lorenzo, Sampaio, Ibáñez, \& Ortega, 2008; Ittenbach \& Esters, 1995; Karipidis, Fotinakis, Taxildaris, \& Fatouros, 2001; Kozar, Vaughn, Whitfield, Lord, \& Dye, 1994; Sampaio, Drinkwater, \& Leite, 2010; Sampaio, Lago, Casais, \& Leite, 2010). For example, the defensive rebounds and the percentage of successful field-goals are strongly related to the outcome of male competitions (Ibáñez, Sampaio, Sáenz-López, Giménez, \& Janeira, 2003; Sampaio \& Janeira, 2003; Trninić, Dizdar, \& Lukšić, 2002). However, the percentage of successful 3-point field- goals and assists are the best discriminators between women's winning and losing teams (Gómez, Lorenzo, Sampaio, \& Ibáñez, 2006; Gómez, Lorenzo, Ortega, Sampaio, \& Ibáñez, 2009).

All these results suggest that effectiveness in collective movement patterns varies according to gender. In fact, Sampaio, Ibáñez, and Feu (2004) found that men's team performances were best discriminated from women's teams by their higher percentage of blocks, lower percentage of steals and unsuccessful 2-point field-goals. Accordingly, João, Leite, Mesquita, and Sampaio (2010) identified gender differences in volleyball game-related statistics, with men's performances being associated with terminal actions (errors of service), but women's performances being characterised by continuous actions (in defence and attack). These differences were seen as a consequence of anthropometric and physiological differences between genders and need to be accounted for when preparing game strategies. 
In the last few years, several studies examined the effects of situational variables such as game location, match status and quality of the opponent on performance indicators (Gómez \& Pollard, 2011; Lago, 2009; Lago \& Martín, 2007; Marcelino, Mesquita, \& Sampaio, 2011; Sampaio, Lago, \& Drinkwater, 2010; Sampaio, Lago, Casais, et al., 2010; Taylor, Mellalieu, James, \& Shearer, 2008; Tucker, Mellalieu, James, \& Taylor, 2005). In basketball, other situational variables such as the stage of the league may highlight the differences between regular season and playoff games. In fact, different strategies may be used when teams are playing for accumulating points in a regular season compared with competing in a playoff series, with one team facing immediate elimination. Therefore, this specific game context accounts for differences due to the importance of the game perceived in different stages of the league (Gómez et al., 2008; Sampaio \& Janeira, 2003). The game period is also a situational variable of interest in basketball, according to research on critical moments. Some research identified the end of a game (last five minutes) as the most critical moment (Bar-Eli \& Tractinsky, 2000; Kozar, Whitfield, Lord, \& Mechikoff, 1993; Mechikoff, Kozar, Lord, Whitfield, \& Brandenburg, 1990; Navarro, Lorenzo, Gómez, \& Sampaio, 2009). On the other hand, there is also recent research addressing the importance of the starting (first five minutes) periods of the game (Sampaio, Lago, \& Drinkwater, 2010; Sampaio, Lago, Casais, et al., 2010).

Few studies have examined how basketball teams use their opportunities to score (i.e., their ball possession effectiveness) and none has addressed how the situational variables may affect scoring strategies and tactics (Gómez et al., 2010; Remmert, 2003). In fact, players' interactions are constantly present in the games and may influence the different tactical approaches to score or prevent the opponents from scoring (Remmert, 2003). Available research has identified the number of passes, the number of participants and the possession duration of each ball possession as relevant variables to analyse the ball possessions (Gómez, Tsamourtzis, \& Lorenzo, 2006; Ortega, Cárdenas, Sainz de Baranda, \& Palao, 2006a, 2006b). However, other authors have suggested the importance of group tactical offensive and defensive behaviours, such as screens on and off the ball, multiple screens and defensive systems (Gómez et al., 2010; Mexas, Tsiskaris, Kyriakou, \& Garefis, 2005; Mikes, 1987; Remmert, 2003).

Although there is interest in identifying and describing these performance indicators and their effects on ball possession effectiveness, available research is still very scarce when all these dimensions are addressed simultaneously. Therefore, the aim of the present study was to identify the importance of performance indicators in predicting the effectiveness of ball possessions in men's and women's basketball, when controlling for situational variables (league stage, game location and match status) and game periods (first five minutes, middle thirty minutes and last five minutes). For each gender, we hypothesised that playing tactics are influenced by the situational variables in each game period.

\section{Method}

\section{Sample and variables}

The sample consisted of 7234 ball possessions (men's teams $=3523$; women's teams $=3711)$, corresponding to 40 games (10 regular season and 10 playoff games for each gender) from the 2006-2007 Spanish men's and women's professional basketball league, with mean score differences of $7.1 \pm 0.8$ and $6.3 \pm 0.7$, respectively. The games were provided by the Spanish Basketball Federation after being randomly selected from those available on the public TV. The games ending with overtime were excluded from the sample. Ethics approval was obtained both from the Spanish Basketball Federation and the Faculty of Physical Activity and Sport Sciences of the Polytechnic University of Madrid.

The ball possession effectiveness was transformed into a dichotomous dependent variable: the successful ball possessions (when the offensive team scored a 2 or a 3-point field-goal, recovered a ball, secured a rebound or received a foul, including foul shot), and the unsuccessful ball possessions (when the offensive team missed a 2 or 3-point field-goal, received a block shot, committed a foul, made a turnover or made any other rule violation).

The independent variables were related to zone, task and players' position. The zone was studied by the possession starting and possession ending areas of the court. Sixteen different basketball court zones were established (Hughes \& Franks, 2004), namely zone $\mathrm{A}, \mathrm{B}, \mathrm{C}, \mathrm{D}, \mathrm{E}, \mathrm{F}, \mathrm{G}$ and zone $\mathrm{O}$ in the defensive half and zone $\mathrm{I}, \mathrm{J}, \mathrm{K}, \mathrm{L}, \mathrm{M}, \mathrm{N}, \mathrm{H}$ and zone $\mathrm{P}$ in

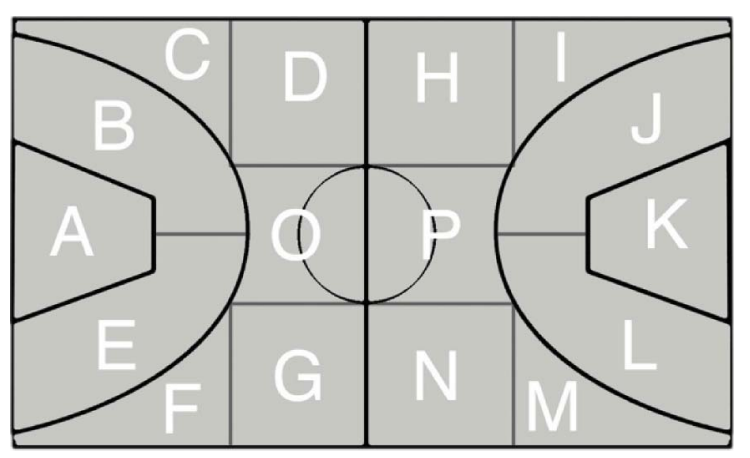

Figure 1. Basketball court zones used in relation to playing tactics (adapted from Hughes \& Franks, 2004). 
the offensive half of the playing court (Figure 1). The players' positions on court were defined as guards, forwards or centres (Ackland, Schreiner, \& Kerr, 1997; Carter, Ackland, Kerr, \& Stappf, 2005; Trninić, Dizdar, \& Dežman, 2000).

The task-related variables included (i) the number of passes used by each team during the ball possession (one, two, three, four, or five or more passes used); ii) the number of players involved in the ball possession (one, two, three, four or five participants); iii) the defensive systems used by the defensive team (man-to-man, zone, press and combined defences); iv) the ball possession duration (0 to 4 seconds, 5 to 10 seconds, 11 to 15 seconds, 16 to 20 seconds, and 21 to 24 seconds); and v) the screens used (no screen used, only screens on used - when the screener sets a screen to the offensive player that handles the ball, only screens off used - when the screener sets a screen to an offensive player without the ball, and screen on and screen off used - when both types of screen were used).

In order to control for the effects of the situational variables, game location (playing at home or away), league stage (regular season and playoff games) and match status were introduced in the models as covariates. Match status was obtained using the accumulative differences between points scored and allowed in each ball possession and then converted into a categorical variable using a two-step cluster analysis (Marcelino et al., 2011; Sampaio, Drinkwater, et al., 2010; Sampaio, Lago, \& Drinkwater, 2010). Five clusters were identified and categorised as "high disadvantage" (differences between -10 and -7 points), "moderate disadvantage" (differences between -6 and -3 points), "balanced" (differences between -2 and 2 points), "moderate advantage" (differences between 3 and 7 points) and "high advantage" (differences between 7 and 13 points). For each gender, the sample was stratified in order to build separate models for three game periods (first five minutes, middle thirty minutes, and the last five minutes of the games) (Sampaio, Lago, Casais, et al., 2010; Sampaio, Lago, \& Drinkwater, 2010).

\section{Procedures}

The 40 games were analysed through systematic observation performed by four expert technicians trained for this task, all graduated in Sports Sciences with a minimum of five years' experience as basketball coaches. After a 3-week period, to prevent any learning effect, each team re-analysed one randomly selected game. Weighted kappa correlation coefficients were calculated to assess inter-observer and intra-observer reliability (O’Donoghue, 2010; Robinson \& O’Donoghue,
2007). The obtained results showed very good kappa values (range $=0.84-0.95$ ) for intra-observer reliability, while inter-observer reliability showed good and very good values (range $=0.80-0.91$ ) according to Altman (1991).

\section{Statistical analysis}

Binary logistic regression was used to estimate regression weights and odds ratios of the relation between performance indicators and covariates according to ball possession effectiveness (Bar-Eli, Tenenbaum, \& Geister, 2006; Marcelino et al., 2011). In this nonlinear model of regression, the estimated regression coefficients represent the estimated change in the logodds, corresponding to a unit change in the corresponding explanatory variable conditional on the other explanatory variables remaining constant (Landau \& Everitt, 2004). The performance indicators were tested individually and later, the adjusted model was performed with all variables that previously showed relation to ball possession effectiveness (Landau \& Everitt, 2004). Odds ratios (OR) and their $95 \%$ confidence intervals (CI) were calculated and adjusted for ball possession effectiveness. The successful ball possessions was the level of the dependent variable with the $\mathrm{OR}$ baseline value $(\mathrm{OR}=1)$. The observations were considered as independent sampling units, assuming that behaviour during ball possessions configure unique interactions between combinations of players and opponents regulated by unpredictable task and environment-related functional information (Duarte, Araújo, Correia, \& Davids, 2012). The team ability was disregarded in this analysis because the focus of the study was not to compare between teams and there are unlikely to be large differences in ability between teams competing in elite professional leagues (Pollard \& Pollard, 2005). Also, the approach to study ball possessions separating three game periods would be conflicting with an overall game measure such as team ability. The statistical analyses were performed using SPSS for Windows, version 16.0 (SPSS Inc., Chicago IL), and statistical significance was set at $P<0.05$.

\section{Results}

The distribution of relative frequencies from the studied variables across the three game periods for men's and women's basketball teams are showed in Table I and Table II, respectively.

In the first stage, when the models of the binary logistic regression were computed with one variable at each step (Table III), the results showed that in both genders, during the first five minutes, there were relations between ball possession effectiveness and number of passes used and ending 
Table I. Distribution of relative frequencies from the studied variables across the three game periods in men's basketball.

\begin{tabular}{|c|c|c|c|c|c|c|c|}
\hline indicators & $(n=464)(\%)$ & $(n=2576)(\%)$ & $(n=483)(\%)$ & indicators & $(n=464)(\%)$ & $(n=2576)(\%)$ & $(n=483)(\%)$ \\
\hline Efficacy & & & & Task (cont.) & & & \\
\hline Successful & 50.0 & 49.5 & 56.6 & Screens used & & & \\
\hline Unsuccessful & 50.0 & 50.5 & 43.5 & No screens & 27.6 & 29.7 & 44.9 \\
\hline A & 32.1 & 38.4 & 35.0 & Screens on/off & 24.4 & 22.4 & 13.5 \\
\hline B & 15.1 & 15.8 & 17.0 & Defensive system & & & \\
\hline $\mathrm{C}$ & 2.2 & 2.5 & 2.5 & Man-to-man & 92.0 & 87.0 & 72.9 \\
\hline $\mathrm{D}$ & 2.2 & 3.0 & 2.1 & Zone & 1.9 & 5.4 & 8.1 \\
\hline $\mathrm{E}$ & 11.6 & 12.2 & 14.1 & Press & 5.6 & 6.6 & 19.0 \\
\hline I & 2.6 & 2.3 & 2.3 & $5-10$ & 23.7 & 18.8 & 25.5 \\
\hline $\mathrm{J}$ & 1.5 & 2.1 & 3.1 & $11-15$ & 28.2 & 29.3 & 23.6 \\
\hline $\mathrm{K}$ & 7.8 & 6.1 & 6.6 & $16-20$ & 21.6 & 22.5 & 17.0 \\
\hline $\mathrm{L}$ & 2.6 & 2.2 & 1.0 & $21-24$ & 5.2 & 8.7 & 8.7 \\
\hline$M$ & 3.9 & 1.5 & 1.7 & Players' position & & & \\
\hline $\mathrm{N}$ & 2.8 & 2.6 & 5.0 & Starting Player & & & \\
\hline $\mathrm{O}$ & 3.2 & 1.7 & 1.0 & Guard & 55.6 & 56.3 & 55.7 \\
\hline $\mathrm{P}$ & 1.9 & 1.9 & 2.1 & Forward & 21.1 & 19.1 & 18.8 \\
\hline Ending zone & & & & Centre & 23.3 & 24.6 & 25.5 \\
\hline $\mathrm{A}$ & 1.1 & 0.9 & 3.5 & Ending Player & & & \\
\hline $\mathrm{B}$ & 0.2 & 0.3 & 0.8 & Guard & 21.8 & 23.5 & 26.7 \\
\hline $\mathrm{C}$ & 0.2 & 0.2 & 0.2 & Forward & 34.5 & 36.8 & 37.3 \\
\hline $\mathrm{L}$ & 2.2 & 7.4 & 4.6 & Covariates & & & \\
\hline M & 6.7 & 9.5 & 1.0 & Game Location & & & \\
\hline $\mathrm{N}$ & 1.1 & 1.4 & 9.1 & Home & 52.5 & 49.7 & 51.8 \\
\hline $\mathrm{O}$ & 2.2 & 0.4 & 3.5 & Away & 47.5 & 50.3 & 48.2 \\
\hline $\mathrm{P}$ & 6.2 & 7.4 & 0.8 & League Stage & & & \\
\hline Task & & & & Regular season & 49.5 & 50.7 & 50.1 \\
\hline Passes used & & & & Playoff & 50.5 & 49.3 & 49.1 \\
\hline 0 & 9.5 & 8.3 & 9.1 & Match Status & & & \\
\hline 1 & 13.8 & 15.6 & 19.9 & $\begin{array}{l}\text { High } \\
\text { disadvantage }\end{array}$ & 0.2 & 7.9 & 13.9 \\
\hline 2 & 20.9 & 20.2 & 25.5 & $\begin{array}{l}\text { Mod } \\
\text { disadvantage }\end{array}$ & 15.5 & 21.9 & 28.4 \\
\hline 3 & 19.2 & 17.5 & 17.8 & Balanced & 68.4 & 39.2 & 18.2 \\
\hline 4 & 15.1 & 15.7 & 12.0 & Mod advantage & 15.4 & 25.0 & 30.6 \\
\hline+5 & 21.6 & 22.8 & 15.7 & High advantage & 0.5 & 6.0 & 8.9 \\
\hline
\end{tabular}

player. Men's and women's teams' results showed relations with starting and ending zone and screens used during the middle thirty minutes. Conversely, no relations were identified for both genders during the last five minutes. In addition for men's teams, there were relations between effectiveness and screens used during the first five minutes (Table III), with defensive systems and possession duration during the middle thirty minutes, and with passes used, possession duration and players involved during the last five minutes. For women's teams, there were additional relations between effectiveness and starting and ending zone and defensive systems during the first five minutes, and no additional relations were found during the middle thirty minutes and 
Table II. Distribution of relative frequencies from the studied variables across the three game periods in women's basketball.

\begin{tabular}{|c|c|c|c|c|c|c|c|}
\hline \multirow{2}{*}{$\begin{array}{l}\text { Performance } \\
\text { indicators }\end{array}$} & $\begin{array}{l}\text { First five } \\
\min \end{array}$ & $\begin{array}{l}\text { Middle thirty } \\
\min \end{array}$ & $\begin{array}{l}\text { Last five } \\
\min \end{array}$ & \multirow{2}{*}{$\begin{array}{l}\text { Performance } \\
\text { indicators }\end{array}$} & $\begin{array}{l}\text { First five } \\
\min \end{array}$ & $\begin{array}{l}\text { Middle thirty } \\
\min \end{array}$ & $\begin{array}{l}\text { Last five } \\
\min \end{array}$ \\
\hline & $(n=822)(\%)$ & $(n=2538)(\%)$ & $(n=351)(\%)$ & & $(n=822)(\%)$ & $(n=2538)(\%)$ & $(n=351)(\%)$ \\
\hline Efficacy & & & & Task (cont.) & & & \\
\hline Successful & 41.0 & 41.8 & 45.0 & Defensive system & & & \\
\hline Unsuccessful & 59.0 & 58.2 & 55.0 & Man-to-man & 90.4 & 84.4 & 74.1 \\
\hline A & 34.3 & 37.1 & 35.9 & Combined & 0.4 & 1.3 & 0.6 \\
\hline B & 13.5 & 11.5 & 12.3 & Screens used & & & \\
\hline $\mathrm{C}$ & 4.0 & 3.4 & 5.1 & No screens & 49.4 & 52.2 & 57.0 \\
\hline $\mathrm{D}$ & 2.9 & 2.7 & 4.0 & Screens on & 8.4 & 9.7 & 10.0 \\
\hline $\mathrm{E}$ & 13.3 & 14.0 & 10.8 & Screens off & 32.1 & 27.1 & 23.9 \\
\hline $\mathrm{F}$ & 3.0 & 4.1 & 4.6 & Screens on and off & 10.1 & 10.9 & 9.1 \\
\hline I & 2.6 & 3.3 & 1.7 & $5-10$ & 24.5 & 21.1 & 20.8 \\
\hline $\mathrm{J}$ & 1.7 & 3.0 & 3.4 & $11-15$ & 29.9 & 28.8 & 25.4 \\
\hline $\mathrm{K}$ & 9.2 & 7.9 & 4.3 & $16-20$ & 22.6 & 23.3 & 20.2 \\
\hline $\mathrm{L}$ & 2.2 & 2.2 & 2.8 & $21-24$ & 5.5 & 8.4 & 8.8 \\
\hline$M$ & 3.2 & 2.1 & 2.3 & Players' position & & & \\
\hline $\mathrm{N}$ & 1.6 & 1.5 & 2.3 & Starting Player & & & \\
\hline $\mathrm{O}$ & 1.9 & 1.6 & 1.7 & Guard & 56.1 & 48.3 & 36.8 \\
\hline $\mathrm{P}$ & 1.9 & 0.9 & 1.7 & Forward & 21.9 & 24.3 & 31.3 \\
\hline Ending zone & & & & Centre & 22.0 & 27.3 & 31.9 \\
\hline $\mathrm{A}$ & 0.7 & 0.9 & 3.1 & Ending Player & & & \\
\hline $\mathrm{B}$ & 1.1 & 0.4 & 1.1 & Guard & 20.2 & 18.6 & 21.9 \\
\hline $\mathrm{C}$ & 0.2 & 0.3 & 0.3 & Forward & 38.1 & 42.6 & 49.6 \\
\hline $\mathrm{L}$ & 12.7 & 11.0 & 9.7 & Covariates & & & \\
\hline M & 8.0 & 7.4 & 9.4 & Game Location & & & \\
\hline $\mathrm{N}$ & 1.9 & 0.8 & 3.4 & Home & 51.0 & 49.5 & 48.2 \\
\hline $\mathrm{O}$ & 0.4 & 0.8 & 0.9 & Away & 49.0 & 50.5 & 51.2 \\
\hline $\mathrm{P}$ & 4.4 & 3.9 & 7.4 & League Stage & & & \\
\hline Task & & & & Regular season & 59.3 & 46.4 & 44.8 \\
\hline Passes used & & & & Playoff & 40.7 & 53.6 & 55.2 \\
\hline 0 & 15.1 & 12.7 & 14.0 & Match Status & & & \\
\hline 1 & 16.9 & 17.1 & 21.9 & High disadvantage & 5.2 & 11.0 & 13.9 \\
\hline 2 & 21.3 & 21.0 & 19.9 & $\begin{array}{l}\text { Moderate } \\
\text { disadvantage }\end{array}$ & 17.8 & 20.7 & 28.9 \\
\hline 3 & 22.0 & 18.4 & 14.0 & Balanced & 52.1 & 37.4 & 20.4 \\
\hline 4 & 13.4 & 13.9 & 17.9 & Moderate advantage & 19.3 & 18.9 & 13.3 \\
\hline+5 & 11.3 & 17.0 & 12.3 & High advantage & 5.6 & 12.0 & 25.5 \\
\hline
\end{tabular}

the last five minutes. The likelihood ratio tests (LRT) identified that the covariates (league stage, game location and match status) were not related with ball possession effectiveness in men's teams. In women's teams, the covariates match status was related with ball possession effectiveness during the first five minutes, and league stage was related with ball possession effectiveness during the middle thirty minutes and last five minutes. Finally, match status was related with effectiveness during the last five minutes of the games in women's teams (Table III).

In Table III, the adjusted model fitted the three game period in men's (first five minutes: LRT = 80.6, df $=10, P<0.01$; middle thirty minutes: LRT $=320.5, \mathrm{df}=41, P<0.0001$; last five minutes: LRT $=120.1, \mathrm{df}=13, P<0.0001)$ and women's teams (first five minutes: $\mathrm{LRT}=164.8, \mathrm{df}=44$, 
Table III. Model and fit information for the frequency of performance indicators during the game periods according to ball possession effectiveness in men's and women's teams.

\begin{tabular}{|c|c|c|c|c|c|c|}
\hline & \multicolumn{6}{|c|}{ Chi-Square of Likelihood Ratio } \\
\hline \multicolumn{7}{|l|}{ Space } \\
\hline Starting zone & 21.7 & $28.6^{\star}$ & $26.2^{\star}$ & $60.5^{\star \star \star}$ & 15.5 & 22.0 \\
\hline Passes used & $13.4^{\star \star}$ & $19.5^{\star \star}$ & 6.8 & 3.2 & $12.3^{\star}$ & 1.5 \\
\hline Defensive system & 1.8 & $12.7^{\star \star}$ & $12.2^{\star \star}$ & 5.7 & 1.2 & 1.9 \\
\hline Screens used & $10.2^{\star}$ & 3.7 & $18.4^{\star \star \star}$ & $14.0^{\star \star}$ & 1.9 & 4.5 \\
\hline Possession duration & 9.1 & 3.4 & $59.1^{\star \star \star}$ & 6.1 & $25.2^{\star \star \star}$ & 1.3 \\
\hline \multicolumn{7}{|l|}{ Players' position } \\
\hline Starting player & 1.0 & 1.2 & 4.9 & 2.6 & 4.5 & 4.7 \\
\hline League Stage & 0.1 & 2.6 & 1.5 & $12.1^{\star \star \star}$ & 1.1 & $4.8^{\star}$ \\
\hline Match Status & 1.2 & $3.9^{\star}$ & 2.9 & 2.7 & 3.5 & $14.0^{\star \star \star}$ \\
\hline Adjusted model & $80.6^{\star \star}$ & $164.8^{\star \star \star}$ & $320.5^{\star \star \star}$ & $196.9^{\star \star \star}$ & $120.1^{\star \star \star}$ & $99.3^{\star \star \star}$ \\
\hline \multicolumn{7}{|l|}{ Space } \\
\hline Starting zone & & $29.6^{\star}$ & $25.5^{\star}$ & $64.2^{\star \star \star}$ & & \\
\hline Ending zone & & $76.1^{\star \star \star}$ & $111.3^{\star \star \star}$ & $69.3^{\star \star \star}$ & & \\
\hline \multicolumn{7}{|l|}{ Task } \\
\hline Passes used & $19.6^{\star \star \star}$ & $18.0^{\star \star}$ & & & $12.3^{\star}$ & \\
\hline Defensive system & & $13.6^{\star \star}$ & $11.9^{\star \star}$ & & & \\
\hline Screens used & 4.2 & & $16.9^{\star \star \star}$ & $9.7^{\star}$ & & \\
\hline Possession duration & & & $70.9^{\star \star \star}$ & & $29.7^{\star \star \star}$ & \\
\hline
\end{tabular}

${ }^{\star} P<0.05,{ }^{\star \star} P<0.01,{ }^{\star \star \star} P<0.001$.

$P<0.0001$; middle thirty minutes: LRT $=196.9$, df $=34, P<0.0001$; last five minutes: $\mathrm{LRT}=99.3, \mathrm{df}$ $=5, P<0.0001)$.

Men's and women's teams showed similar patterns with relations between possession effectiveness and passes used (LRT $=19.6, \mathrm{df}=5, P=0.01$ and $\mathrm{LRT}=18.0, \mathrm{df}=5, P=0.003$, respectively) and ending player $(\mathrm{LRT}=6.7, \mathrm{df}=2, P=0.03$ and LRT $=10.5, \mathrm{df}=2, P=0.005$, respectively) during the first five minutes. Furthermore, both genders showed similar relations with starting zone (LRT = 25.5, $\mathrm{df}=15, P=0.04$ and LRT $=64.2, \mathrm{df}=15$, $P<0.001$, respectively), ending zone (LRT $=111.3$, $\mathrm{df}=15, P<0.001$ and $\mathrm{LRT}=69.3$, $\mathrm{df}=15$, $P<0.001$, respectively), and with screens used $(\mathrm{LRT}=16.9, \mathrm{df}=3, P=0.001$ and $\mathrm{LRT}=9.7$, $\mathrm{df}=3, P=0.022$, respectively) during the middle thirty minutes. Conversely, no similar relations by gender were found during last five minutes.

In addition, men's teams showed relations between ball possession effectiveness and defensive systems $(\mathrm{LRT}=11.9, \mathrm{df}=3, P=0.007)$ and possession duration (LRT $=70.9, \mathrm{df}=4, P<$ $0.001)$ during the middle thirty minutes. Also the results showed that there were relations with passes used $(\mathrm{LRT}=12.3, \mathrm{df}=5, P=0.030)$, possession duration (LRT $=29.7, \mathrm{df}=4, P<$ $0.001)$ and players involved (LRT $=17.7, \mathrm{df}=4$, $P=0.01)$ during the last five minutes. Conversely, women's teams showed additional relations between possession effectiveness and starting $(\mathrm{LRT}=29.6, \mathrm{df}=15, P=0.013)$ and ending zone $(\mathrm{LRT}=76.1, \mathrm{df}=15, P<0.001)$, and defensive systems $(\mathrm{LRT}=13.6, \mathrm{df}=3, P=$ $0.004)$ during the first five minutes. Some covariates were associated with ball possession effectiveness in women's basketball. Specifically, the league stage was significant during the middle thirty minutes $($ LRT $=6.2, \mathrm{df}=1, P<0.001)$ and the last five minutes $(\mathrm{LRT}=8.1$, $\mathrm{df}=1, P=0.004)$, and match status during the last five minutes $($ LRT $=$ 13.1, df $=4, P<0.001$ ). 
Table IV. Results of success in ball possessions as a function of performance indicators used by men's and women's teams.

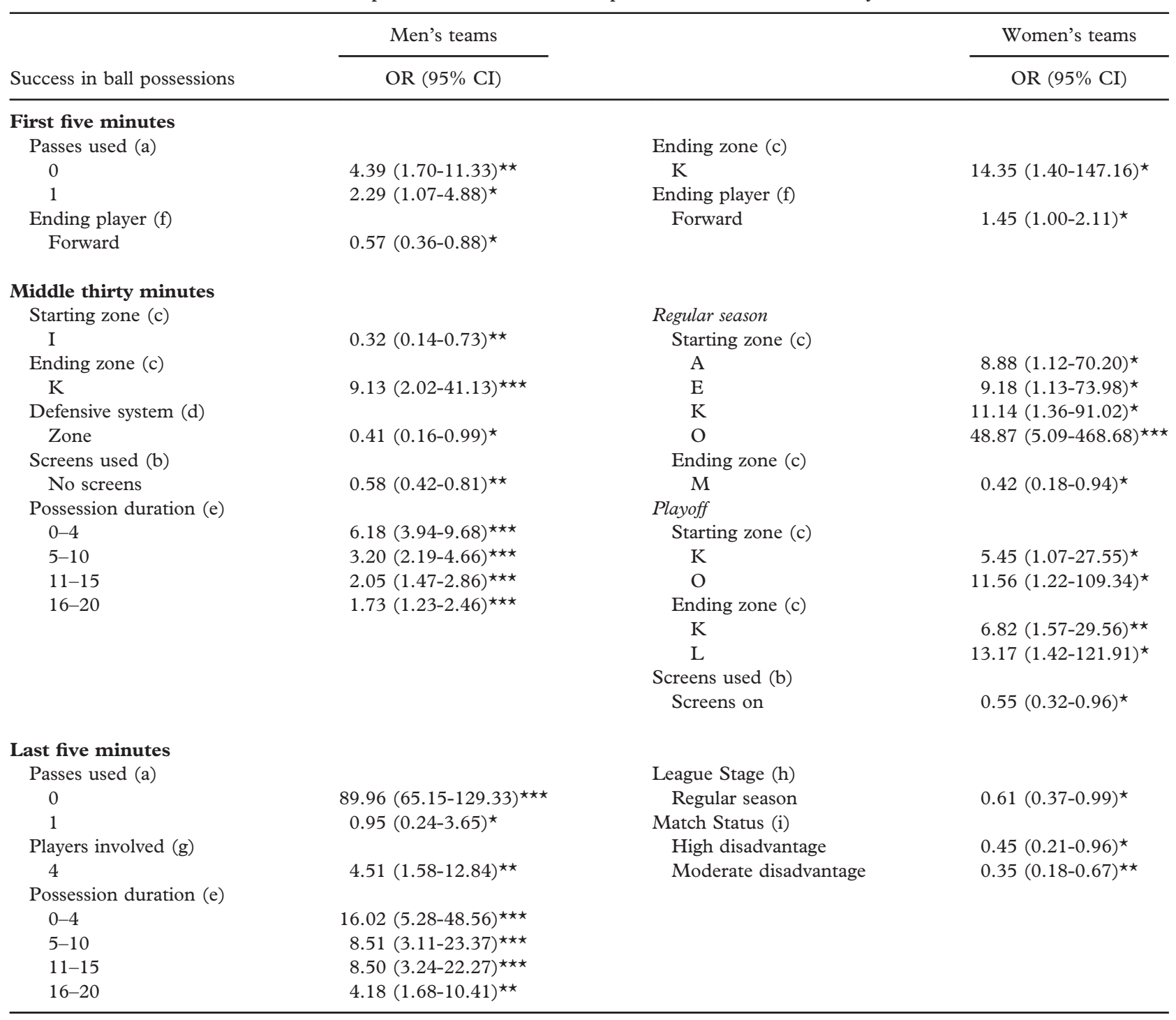

${ }^{\star} P<0.05,{ }^{\star \star} P<0.01,{ }^{\star \star \star} P<0.001 ; \mathrm{OR}$, odds ratios; CI, confidence intervals. The baseline categories when OR = 1 were: (a) more than 5 passes; (b) screens on and off; (c) zone P; (d) combined defence; (e) 21-24 seconds; (f) centre; (g) 5 players; (h) playoff; and (i) high advantage.

The results obtained in men's basketball showed the highest ball possession effectiveness when they end the ball possessions in zone $\mathrm{K}(\mathrm{OR}=9.13)$ and when they used possession durations ranging between 0 and 4 seconds $(O R=6.18), 5$ and 10 seconds $(\mathrm{OR}=3.20), 11$ and 15 seconds $(\mathrm{OR}=$ $2.05)$, and 16 and 20 seconds $(O R=1.73)$ during the middle thirty minutes (Table IV). However, the ball possession effectiveness was reduced when men's teams used no screens $(\mathrm{OR}=0.58)$, when they played versus zone defences $(\mathrm{OR}=0.41)$, and when they initiated the ball possession in zone I (OR $=0.32$ ). On the other hand, in women's basketball, the covariate league stage was significant, and therefore two independent models were considered. First, women's teams reduced the possession effectiveness when they end the ball possessions in zone $M(\mathrm{OR}=$ 0.42), and the ball possession effectiveness was increased when they initiated the ball possessions in zones $\mathrm{O}(\mathrm{OR}=48.87), \mathrm{K}(\mathrm{OR}=11.14), \mathrm{E}(\mathrm{OR}=$ 9.18), and $A(O R=8.88)$ during the regular season (Table IV). Conversely, women's teams reduced the ball possession effectiveness when they use the screens on $(\mathrm{OR}=0.55)$ and the ball possession effectiveness was increased when they initiated their ball possessions in zones $\mathrm{O}(\mathrm{OR}=11.56)$ and $\mathrm{K}$ $(\mathrm{OR}=5.45)$, and when they ended their ball possessions in zones $\mathrm{L}(\mathrm{OR}=13.17)$ and $\mathrm{K}(\mathrm{OR}=6.82)$ during the playoff games.

Results also showed that men's basketball teams obtained more successful ball possessions when they used one $(\mathrm{OR}=4.39)$ or no passes $(\mathrm{OR}=2.29)$ 
during the first five minutes (Table IV). However, their ball possession effectiveness was reduced when ball possessions ended with the forward players $(\mathrm{OR}=0.57)$. On the other hand, in women's basketball, the ball possession effectiveness increased when ball possessions ended in zone $\mathrm{K}(\mathrm{OR}=14.35)$ and when ball possessions ended with the forward players $(\mathrm{OR}=1.45)($ Table IV).

Finally, Table IV shows that men's teams increased ball possession effectiveness when possession duration ranged between 0 and 4 seconds $(\mathrm{OR}=16.02), 5$ and 10 seconds $(\mathrm{OR}=8.51), 11$ and 15 seconds $(O R=8.50)$, and 16 and 20 seconds $(\mathrm{OR}=4.18)$, when they used no passes $(\mathrm{OR}=$ 89.96), and when ball possessions involved 4 players $(\mathrm{OR}=4.51)$ during the last five minutes. Conversely, the ball possession effectiveness was lower when only 1 pass was used $(\mathrm{OR}=0.95)$. On the other hand, women's teams showed that two covariates (league stage and match status) were significant. However, no statistically significant relations were found between possession effectiveness and performance indicators. The effects of league stage and possession effectiveness showed lower effectiveness values during playoff games $(\mathrm{OR}=$ $0.61)$. Also, there was reduced ball possessions effectiveness when scores were unbalanced with high disadvantage $(\mathrm{OR}=0.45)$ and moderate disadvantage $(\mathrm{OR}=0.35)$ in regular season and playoff games.

\section{Discussion}

The aim of the present study was to identify the importance of performance indicators to predict the effectiveness of ball possessions in men's and women's basketball, when controlling for situational variables (league stage, game location and match status) and game periods (first five minutes, middle thirty minutes and last five minutes). It was reasoned that these results could contribute to increase tactical knowledge, both for the prescription of specific drills in practice sessions and for making decisions in competition. We hypothesised that some playing tactics lead to higher effectiveness in ball possessions and that these may be influenced by situational variables. Also, different models were built to describe the optimum playing tactics during each game period for men's and women's basketball.

In general, the results supported these hypotheses and allowed the description and modelling of basketball performance in the presented scenarios. The situational variables only affected the women's games. It is possible that slower game pace (Oliver, 2004) and increased susceptibility to environmental changes (Pendleton, 2001) provide explanations for these results. It seems likely that the importance of each action is increased when playing at lower paces and their contribution to the changes in match status and league stage can also become higher.

There were substantial differences in optimal tactics for men's and women's teams in the three game periods. In fact, the possibility that basketball teams may have used different game tactics in each of these match periods was already recognised (Bar-Eli \& Tractinsky, 2000; Kozar et al., 1993; Mechikoff et al., 1990; Navarro et al., 2009). However, the information from these previous studies is not specific to different situational variables.

\section{Men's basketball league}

The current results show that men's teams increased the probability of obtaining a successful ball possession with only one pass or no passes at all during the first five minutes of the games. This may show that both teams are trying to be acquainted with the opponents' weakness, and they use one-on-one situations and fast-breaks with only one pass more frequently, allowing them to receive a foul or score a basket (Fotinakis, Karipidis, \& Taxildaris, 2002). Conversely, when teams used the forward players to end their ball possessions during this period, they had lower chances of obtaining success. This result may suggest the importance of initial defence, in particular defensive actions that impel the offensive team to shoot from difficult situations or far from the 3-point line (Mexas et al., 2005).

Men's teams obtained more successful ball possessions when ball possessions ended in zone $\mathrm{K}$ (inside the restricted area), and possession durations ranged between 0 and 20 seconds during the middle thirty minutes of the game. These possession durations suggest that teamwork plays an important role in basketball (Mavridis, Laios, Taxildaris, \& Tsiskaris, 2003), in particular the collective tactical decisions that enable the creation of optimal space-time fieldgoal opportunities inside the paint (Gómez et al., 2008). The teams had lower success when they did not use screens and attacked against zone defences. These results support the idea that screening is associated with more points per possession (Remmert, 2003) as they allow the provision of extra space and time to play by relieving the defensive pressure. Also, zone defences allow modifying the game pace, disturbing the offence, and forcing a change in offensive movements (Mikes, 1987; Mexas et al., 2005). Thus, the results seem to suggest that coaches should prepare different game strategies such as screens on and off the ball to attack against zone defences during the middle thirty minutes of games.

Finally, men's teams increased possession effectiveness by using no passes or four players or possession durations between 0 and 20 seconds during the last five minutes. Sampaio, Lago, and Drinkwater 
(2010) stated that at the end of the game the strategic decisions are more conservative, because teams feel the importance of those moments and choose the less risky options. The present study included games with relatively small point differences (7.1 \pm 0.8 ), then the use of more controlled game styles during the last five minutes may indeed reduce risks, for example by preventing turnovers (Trninić et al., 2002). In this way, two different tactics seem to be related with possession effectiveness during the last five minutes. First, the use of no passes may suggest a ball-recovered situation that allowed benefiting from an advantageous position to score. Ortega et al. (2006a, 2006b) also reported that during the last five minutes the game seems too focused on one player, with possible consequences of decreasing the game pace and increasing predictability. Second, the use of four players and durations ranging from 0 to 20 seconds allow exploring of collective team plays in order to create space and time near to the basket (Kozar et al., 1994; Mavridis et al., 2003). However, when only one pass was used, the probability of obtaining successful ball possessions was reduced.

\section{Women's basketball league}

The results from the women's teams were different, as higher efficacies were obtained when ending the actions with forward players in zone $\mathrm{K}$ during the first five minutes. These results may suggest that forward players have additional importance in women's basketball, probably because they are more involved in defensive actions (i.e., ball recovery and fast break situations) and offensive actions (i.e., shooting from good positions inside the paint instead of near the 3-point line as occurs in men's games) (Mavridis et al., 2003).

Also, the results showed different game styles during regular season and playoff games when analysing the middle thirty minutes period, indicating that league stage is a determinant of ball possession effectiveness in women's basketball (Gómez et al., 2008; Sampaio \& Janeira, 2003). The women's teams obtained higher effectiveness when starting the attack in zones A, E, K and $\mathrm{O}$ during regular season games. These results may reflect that higher efficacy attacks started with defensive and offensive rebounds (zones $\mathrm{A}, \mathrm{E}$ and $\mathrm{K}$ ), and steals (zone O) (Gómez et al., 2006, 2009). However, the effectiveness was higher when starting the attack in zones $\mathrm{K}$ and $\mathrm{O}$, and ending in zones $\mathrm{K}$ and $\mathrm{L}$ during playoff games. These results suggest the importance of defensive pressure in half court with more steals near the middle line (zone $\mathrm{O}$ ), and also the importance of offensive rebounds (zone K). Particularly, the offensive rebound allows for keeping the ball possession and indicates a bad defence that has not secured the defensive rebound (Trninić et al., 2002). Thus, these facts may reflect a lower field-goal percentage from the offensive teams that allows an increased number of actions in zone $\mathrm{K}$, and also indicates the importance of zone $\mathrm{K}$ to secure the defensive rebounds in playoff games (Gómez et al., 2008; Sampaio \& Janeira, 2003).

The use of screens on the ball reduced the ball possession effectiveness, suggesting that screens off the ball and no screens are better tactics for women's teams. In fact, these teams play with a slower game pace and are probably more focused on steals and offensive rebounds to initiate ball possessions (Gómez et al., 2009).

This study suggests that in men's basketball the performance indicators are mostly dependent on game period, whereas in women's basketball the performance indicators are also dependent on situational variables (league stage and match status). The knowledge of these trends should be important when planning for specific practice sessions and when making decisions in competition. Hence, it may be useful to employ more frequently the combinations of playing tactics that have been identified as having higher efficacy. For example, in men's basketball, ball possession efficacy during the last five minutes of the game appeared to depend upon the number of players, the possession duration and number of passes. Further, players' development programmes may also benefit from the current findings on gender-specific differences both from individual and collective perspectives.

\section{References}

Ackland, T. R., Schreiner, A. B., \& Kerr, D. A. (1997). Absolute size and proportionality characteristics of World Championship female basketball players. Fournal of Sports Sciences, 15, 485-490.

Altman, D. G. (1991). Some common problems in medical research. In D. G. Altman (Ed.), Practical statistics for medical research (pp. 403-409). London: Chapman \& Hall.

Bar-Eli, M., Tenenbaum, G., \& Geister, S. (2006). Consequences of players' dismissal in professional soccer: A crisis-related analysis of group-size effects. Fournal of Sports Sciences, 24, 1083-1094.

Bar-Eli, M., \& Tractinsky, N. (2000). Criticality of game situations and decision making in basketball: An application of performance crisis perspective. Psychology of Sport and Exercise, 1, 27-39.

Carter, J. E. L., Ackland, T. R., Kerr, D. A., \& Stappf, A. B. (2005). Somatotype and size of elite female basketball players. fournal of Sports Sciences, 23, 1057-1063.

Duarte, R., Araújo, D., Correia, V., \& Davids, K. (2012). Sports teams as superorganisms: Implications of sociobiological models of behaviour for research and practice in team sports performance analysis. Sports medicine, 42, 633-642.

Fotinakis, P., Karipidis, A., \& Taxildaris, K. (2002). Factors characterising the transition game in European basketball. Fournal of Human Movement Studies, 42, 305-316.

Gómez, M. A., Lorenzo, A., Ibáñez, S. J., Ortega, E., Leite, N., \& Sampaio, J. (2010). An analysis of defensive strategies used by 
home and away basketball teams. Perceptual and Motor Skills, 110, 159-166.

Gómez, M. A., Lorenzo, A., Ortega, E., Sampaio, J., \& Ibáñez, S. J. (2009). Game related statistics discriminating between starters and nonstarters players in women's National Basketball Relation League (WNBA). Fournal of Sports Science and Medicine, 8, 278-283.

Gómez, M. A, Lorenzo, A., Sampaio, J., \& Ibáñez, S. J. (2006). Differences in game-related statistics between winning and losing teams in women's basketball. Fournal of Human Movement Studies, 51, 357-369.

Gómez, M. A., Lorenzo, A., Sampaio, J., Ibáñez, S. J., \& Ortega, E. (2008). Game-related statistics that discriminated winning and losing teams from the Spanish men's professional basketball teams. Collegium Antropologicum, 32, 315-319.

Gómez, M. A., \& Pollard, R. (2011). Reduced home advantage for basketball teams from capital cities in Europe. European Fournal of Sport Science, 11, 143-148.

Gómez, M. A., Tsamourtzis, E., \& Lorenzo, A. (2006). Defensive systems in basketball ball possessions. International fournal of Performance Analysis in Sport, 6, 98-107.

Hughes, M., \& Bartlett, R. (2002). The use of performance indicators in performance analysis. Fournal of Sports Sciences, 20, 739-754.

Hughes, M. D., \& Franks, I. M. (2004). Notational analysis of sport 2nd Edition - a perspective on improving coaching. London: E. \& F. N. Spon.

Ibáñez, S. J., Sampaio, J., Sáenz-López, P., Giménez, J., \& Janeira, M. A. (2003). Game statistics discriminating the final outcome of Junior World Basketball Championship matches (Portugal 1999). Fournal of Human Movement Studies, 45, 1-19.

Ittenbach, R. F., \& Esters, I. G. (1995). Utility of team indices for predicting end of season ranking in two national polls. Fournal of Sport Behavior, 18, 216-225.

João, P.V. , Leite, N., Mesquita, I., \& Sampaio, J. (2010). Sex differences in discriminative power of volleyball game-related statistics. Perceptual and Motor Skills, 111, 893-900.

Karipidis, A., Fotinakis, P., Taxildaris, K., \& Fatouros, J. (2001). Factors characterising a successful performance in basketball. Fournal of Human Movement Studies, 41, 385-397.

Kozar, B., Vaughn, R. E., Whitfield, K. E., Lord, R. H., \& Dye, B. (1994). Importance of free-throws at various stages of basketball games. Perceptual and Motor Skills, 78, 243-248.

Kozar, B., Whitfield, K. E., Lord, R. H., \& Mechikoff, R. A. (1993). Timeouts before free-throws: Do the statistics support the strategy? Perceptual and Motor Skills, 76, 47-50.

Lago, C. (2009). The influence of match location, quality of opposition, and match status on possession strategies in professional relation football. Fournal of Sports Sciences, 27, 1463-1469.

Lago, C., \& Martín, R. (2007). Determinants of possession of the ball in soccer. Fournal of Sport Sciences, 25, 969-974.

Landau, S., \& Everitt, B. (2004). A handbook of statistical analyses using SPSS. Boca Raton, Florida: Chapman \& Hall/CRD.

Marcelino, R., Mesquita, I., \& Sampaio, J. (2011). Effects of quality of opposition and match status on technical and tactical performances in elite volleyball. Fournal of Sport Sciences, 29, 733-741.

Mavridis, G., Laios, A., Taxildaris, K., \& Tsiskaris, G. (2003). Developing offense in basketball after a return pass outside as crucial factor of winning. Inquiries in Sport and Physical Education, 2, 81-86.

Mechikoff, R. A., Kozar, B., Lord, R. H., Whitfield, K. E., \& Brandenburg, J. (1990). Perceptions of basketball coaches. The Basketball Bulletin, Fall, 72-75.

Mexas, K., Tsiskaris, G., Kyriakou, D., \& Garefis, A., (2005). Comparison of effectiveness of organized offences between two different championships in high level basketball. International Fournal of Performance Analysis in Sport, 5, 72-82.

Mikes, J. (1987). Computer breakdown of percentage basketball. Scholastic Coach, 57, 52-54.

Navarro, R. M., Lorenzo, A., Gómez, M. A., \& Sampaio, J. (2009). Analysis of critical moments in the League ACB 2007-2008. Revista de Psicología del Deporte, 18 (suppl.), 391-395.

O'Donoghue, P. (2010). Research methods for sport performance analysis. London: Routledge Taylor \& Francis Group.

Oliver, D. (2004). Basketball on paper. Rules and tools for performance analysis. Washington, DC: Brassey's.

Ortega, E., Cárdenas, D., Sainz de Baranda, P. S., \& Palao, J. M. (2006a). Analysis of the final actions used in basketball during formative years according to player's position. Fournal of Human Movement Studies, 50, 421-437.

Ortega, E., Cárdenas, D., Sainz de Baranda, P. S., \& Palao, J. M. (2006b). Differences in competitive participation according to player's position in formative basketball. Fournal of Human Movement Studies, 50, 103-122.

Pendleton, S. (2001). Motivating female athletes for success in basketball. Scholastic Coach and Athletic Director, 70, 96-97.

Pollard, R., \& Pollard, G. (2005). Long-term trends in home advantage in professional team sports in North America and England (1876-2003). Fournal of Sports Sciences, 23, 337-350.

Remmert, H. (2003). Analysis of group-tactical offensive behavior in elite basketball on the basis of a process orientated model. European fournal of Sport Science, 3, 1-12.

Robinson, G., \& O’Donoghue, P. (2007). A weighted kappa statistic for reliability testing in performance analysis of sport. International fournal of Performance Analysis in Sport, 7, 12-19.

Sampaio, J., Drinkwater, E. J., \& Leite, N. (2010). Effects of season period, team quality, and playing time on basketball players' game-related statistics. European fournal of Sport Sciences, 10, 141-149.

Sampaio, J., Ibáñez, S. J., \& Feu, S. (2004). Discriminative power of basketball game-related statistics by level of competition and sex. Perceptual and Motor Skills, 32, 1231-1238.

Sampaio, J., \& Janeira, M. (2003). Statistical analyses of basketball team performance: Understanding teams' wins and losses according to a different index of ball possessions. International Fournal of Performance Analysis in Sport, 1, 40-49.

Sampaio, J., Lago, C., Casais, L., \& Leite, N. (2010). Effects of starting score-line, game location and quality of opposition in basketball quarter score. European fournal of Sport Sciences, 10, 391-396.

Sampaio, J., Lago, C., \& Drinkwater, E. J. (2010). Explanations for the United States of America's dominance in basketball at the Beijing Olympic Games (2008). Fournal of Sports Sciences, 28, 147-152.

Taylor, J. B., Mellalieu, S. D., James, N., \& Shearer, D. (2008). The influence of match location, quality of opposition and match status on technical performance in professional relation football. Fournal of Sports Sciences, 26, 885-895.

Trninić, S., Dizdar, D., \& Dežman, B. (2000). Empirical verification of the weighted system of criteria for the elite basketball players quality evaluation. Collegium Antropologicum, 24, 443455.

Trninić, S., Dizdar, D., \& Lukšić, E. (2002). Differences between winning and defeated top quality basketball teams in final tournaments of European club championship. Collegium Antropologicum, 26, 521-531.

Tucker, W., Mellalieu, S. D., James, N., \& Taylor, J. B. (2005). Game location effects in professional soccer. A case study. International fournal of Performance Analysis in Sports, $5,23-35$. 